Schulich School of Law, Dalhousie University

Schulich Law Scholars

Articles, Book Chapters, \& Blogs

Faculty Scholarship

2019

Legal Uncertainty and Conflict of Laws in the Application of Statutes of Limitation in Nigeria

Okanga Ogbu Okanga

Follow this and additional works at: https://digitalcommons.schulichlaw.dal.ca/scholarly_works

Part of the Conflict of Laws Commons 


\title{
LEGAL UNCERTAINTY AND CONFLICT OF LAWS IN THE APPLICATION OF STATUTES OF LIMITATION IN NIGERIA - OKANGA OGBU OKANGA*
}

\begin{abstract}
Statutes of limitation, otherwise called limitation laws, are legislative instruments or enactments that specify the timeframe within which an action or claim relating to a particular subject-matter may be brought to court. The implication of such enactments, subject to relevant exceptions, is that once an actionable wrong has occurred, the stipulated timeframe for an action to be instituted begins to run and if it lapses, without an action being instituted, the injured party would no longer be allowed to bring the action to court. The right of action would be deemed to have become "statutebarred." Statutes of limitation are laws made by the legislative arm of government based on its constitutional powers. In Nigeria, there are two main tiers of government (Federal and State), with each having power to enact such laws. There appears, however, not to be clear rules defining the scope of application of the statutes of limitation enacted by the various legislative houses at Federal and State levels. Thus, there are scenarios of apparent conflict where it appears that more than one statute of limitation may govern a particular case. This scenario represents a challenge for litigants since the limitation periods prescribed for a given cause of action-say tort-are not always be the same in the respective statutes of limitation that may potentially apply. This article examines the scope of the constitutional powers of the two main tiers of government in Nigeria to legislate on the subject of limitation of actions, the intersection of laws made pursuant to those powers and how these may impact on the pursuit and defence of claims by litigants, especially when those claims cross state lines, border on Federal subjects or border on the administrativelexecutive actions of Federal authorities. We hammer that there is an uncomfortable greyness here which requires better clarity.
\end{abstract}

\section{Introduction}

For litigation lawyers, when a client presents a case in chambers for possible litigation, there is an onus to consider certain preliminary factors before approaching the court. These factors include: the cause of action, the justiciability of the cause of action, the client's legal standing, the court(s) with jurisdiction, pre-action notice, arbitration clauses, the mode of commencement and whether the action is caught by a statute of limitation. ${ }^{1}$

\footnotetext{
* Okanga Ogbu Okanga; Dispute Resolution and Corporate Commercial Lawyer, Tax Consultant; 16D Akin-Olugbade Street, Victoria Island, Lagos; okangaokanga2@gmail.com

${ }^{1}$ The list of considerations is not exhaustive and may vary from case to case. See: Goulding S., (1996) 'Odgers on Civil Court Actions', Sweet \& Maxwell; Ogbu O.S., (2013) ‘Modern Nigerian Legal System’ Snaap Press Ltd. $3^{\text {rd }}$ ed.
} 
Limitation of action is a very important consideration in the sense that it has the potential to render a perfectly good cause unactionable. ${ }^{2}$ This legal impediment has in recent time received greater attention as a result of the Supreme Court of Nigeria's decision in Sifax (Nig.) Ltd v. Migfo (Nig.) $L t d .{ }^{3}$ In that case, the Supreme Court established a landmark precedent to the effect that time pauses for the entire time when an action is in court. ${ }^{4}$ In essence, if, for instance, a litigant commences an action in the wrong court and that action is struck out after a long period of time the period when the action was in court would not count in the computation of time for the purpose of limitation; and the litigant may still be able to refile in the appropriate despite the enormity of time that may have passed.

The Sifax (Nig.) Ltd v. Migfo (Nig.) $L t d .^{5}$ decision has since attracted ample reactions from the Nigerian legal community. ${ }^{6}$ The decision added an important perspective to the statute of limitation question whilst, perhaps, reamplifying the need for lawyers to approach the subject with renewed caution. To be cautious, in our view, also entails standing on the appropriate limitation legislation. This is crucial in a jurisdiction like Nigeria where there are multiple limitation legislations. There are presently Limitation Laws in the various states of the Federation as well as the Limitation Act, an Act of the National Assembly, whose scope of application we shall attempt to discuss herein.

\section{Conflict of Laws}

A conflict of laws usually arises where there is "a difference between the laws of different states or countries in a case in which a transaction or occurrence central to the case has a connection to two or more jurisdictions." ${ }^{\prime 7}$ With regard to statutes of limitation, it is pertinent to note that a cause of action may be subject to different limitation periods in different statutes of limitation. Take, for instance, the Limitation Law of Lagos State specifies that actions founded on simple contract will not be brought after a period of six years from when the cause of action accrued. ${ }^{8}$ In contrast, the

\footnotetext{
${ }^{2}$ See Hassan v Aliyu (2010)17 NWLR (pt.1223) 547.

3 (2018) 9 NWLR (Pt.1623) 138.

${ }^{4}$ The decision upheld that of the Court of Appeal in the same case.

5 Supra.

${ }^{6}$ See: Anjorin A., (2015) 'Statutory Limitation Period and the Legal Basis for Suspension of Time Computation: A Review of Sifax Nigeria Limited v. Migfo Nigeria Limited' The Gravitas Review of Business \& Property Law Vol 6, p. 41; Ibezim O., 'Limitation Of Action: Lost Time Might Not Be Gone Forever - An Analysis Of The Decision In Sifax Nig. Ltd V Migfo Nig. Ltd' https://www.lawyard.ng/limitation-of-action-lost-time-might-not-be-gone-forever-ananalysis-of-the-decision-in-sifax-nig-ltd-v-migfo-nig-ltd-by-onyemauche-ibezim/ retrieved March $16^{\text {th }} 2019$; Nwodo G., 'Time Freezes For Purposes Of The Statute Of Limitation When An Action Is Instituted: The Supreme Court's Decision In Sifax v. Migfo' http://www.mondaq.com/Nigeria/x/686076/trials+appeals+compensation/Time+Freezes+For+Purposes+Of+The+Stat ute+Of+Limitation+When+An+Action+Is+Instituted+The+Supreme+Courts+Decision+In+Sifax+V+Migfo retrieved March 16 $6^{\text {th }}, 2019$.

${ }^{7}$ Black's Law Dictionary (7 ${ }^{\text {th }}$ ed., 1999) pg. 295; Hyd Road \& Others Tech Ltd \& anor v. Abia State Govt \& anor (2014) LPELR-24375(CA).

${ }^{8}$ Section 8 of the Limitation Law of Lagos Sate Cap L84 Laws of Lagos State 2015.
} 
Limitation Law of Delta State specifies a period of five years for actions founded on contract. ${ }^{9}$ Practically, this means that a contract action may not be litigated in Delta State after five years of accrual of the cause of action, but the same claim remains litigable in Lagos State for a further one year. Assuming that the alleged contractual breach occurred in Delta State, but the Defendant resides in Lagos State, the Claimant may on the sixth year - depending on where the law stands on this issue - pursue his claim in Lagos State even though the action has already become statute-barred under the Delta State Limitation Law. This simple illustration, therefore, highlights the fact that a conflict of limitation laws may also induce some forum shopping. ${ }^{10}$

\title{
Nature and essence of statutes of limitation
}

The Black's Law Dictionary defines the term "statute of limitation" as:

"A statute establishing a time limit for suing in a civil case, based on the date when the claim accrued (as when the injury occurred or was discovered)"11

In Adeniyi v. Governing Council, Yaba College of Technology, ${ }^{12}$ the Court of Appeal stated as follows:

\begin{abstract}
"A statute of limitation in a narrower sense of the term, is an enactment of which the primary purpose is to set a time limit - a limitation period on the bringing of legal proceedings in respect of a right of action accruing to a person by virtue of the common law or some statute other than the limitation statute itself. As a corollary, it must define the point of time from which the limitation period is to run, and it may in addition, contain provision for suspending the currency of the period on various grounds" see Nigerian Law of Limitation of Actions by ELAIGWU E. APEH ELALAP Publications) Chapter 1, page 1." Per Danjuma, J.C.A. (P. 21, paras. B-E)
\end{abstract}

A statute of limitation encourages diligent pursuit of claims and discourages the litigation of obsolete causes. In the case of INEC v. Ogbadibo Local Government \& Ors,${ }^{13}$ the Supreme Court had this to say:

“... In ATUNRASE v. SUNMOLA (1985) 1 NWLR (Pt.1) 105 at 120, this court giving

reasons why persons with good causes of action should pursue them with reasonable

\footnotetext{
${ }^{9}$ See section 18 of the Limitation Law of Delta State, Cap L11 Laws of Delta State 2006.

10 This denotes the practice of choosing the most favourable territorial jurisdiction or court in which a matter or cause may be entertained and adjudicated upon. See Mailantarki v. Tongo \& ors (2017) LPELR-42467(SC);

${ }^{11}$ See: Black's Law Dictionary ( $7^{\text {th }}$ ed., 1999) p. 422. See also NNPC v. Emelike (2018) LPELR-44180(CA)

12 (2012) LPELR-8434(CA)

13 (2015) LPELR-24839(SC)
} 
diligence, this court stated thus; "In all actions, suits and other proceedings at law and in equity, the diligent and careful actor or suitor is favoured to the prejudice to him who is careless and slothful, who sleeps over his rights. The law may therefore deny relief to a party who by his conduct has acquiesced or assented to the infraction of his rights, or has led the opposite party responsible for or guilty of such infringement to believe that he has lived (sic) or abandoned his right." It was Abbott C.J in BATTLEY v. FAULKNER 106ER, 668 at 670 who had this to say: "The statute of limitation was intended for the relief and quiet of the defendants and to prevent persons from being harassed at a distant period of time after the committing of the injury complained of." In the case of BOARD OF TRADE v. LAYSER IRVINE \& CO. LTD (1927) A.C. 610 at 628, Lord Atkinson said: "The whole purpose of the Limitation Act is to apply to persons who have good causes of action which they could if so disposed, enforced and to deprive them of power of enforcing them after they have lain by for a number of years respectively and omitted to enforce them. They are thus deprived of the remedy which they have omitted to use." This court, in the case of AJAYI v. ADEBIYI (supra) on the essence of statute of limitation stated as follows:- "The essence of a limitation law is that the legal right to enforce an action is not a perpetual right but a right generally limited by statute. Where a statute of limitation prescribes a period within which an action should be brought, legal proceedings cannot be properly or validly instituted after the expiration of the prescribed period. Therefore, a cause of action is statute-barred if legal proceedings cannot be commenced in respect of same because the period laid down by the limitation law had lapsed. An action which is not brought within the prescribed period, offends the provisions of the law and not give rise to a cause of action. The yardsticks to determine whether an action is statute-barred are: (a) The date when the cause of action accrued. (b) The date of commencement of the suit as indicated in the writ of summons. (c) Period of time prescribed to bringing an action to be ascertained from the statute in question. Time begins to run for the purposes of the limitation law from the date the cause of action accrues..." Per Galadima, J.S.C. (Pp. 30-33, paras. B-D)

Similarly, in Attorney-General of Adamawa State \& Ors v. Attorney-General of the Federation, ${ }^{14}$ the Supreme Court outlined the effect and purpose of a statute of limitation as follows:

"A statute of limitation removes the right of action, the right of enforcement and the right to judicial relief in a plaintiff and leaves him with a bare and empty cause of action which he cannot enforce if the alleged cause of action is statute-barred, that is, if such a cause of action is instituted outside the statutory period allowed by such

${ }^{14}$ (2014) LPELR-23221(SC), 
law. Another way of stating the above proposition is that any action that is commenced after the period stipulated by the statute is totally barred as the right of the plaintiff or the injured person to commence the action would have been extinguished by such law." Per Peter-Odili, J.S.C (P. 31, paras. B-F) ${ }^{15}$

It is evident from the foregoing judicial pronouncements that statutes of limitation derive their origin from equitable principles such as laches, standing by and estoppel. It has long been the case that delay defeats equity and equity takes the side of the vigilant over the indolent. ${ }^{16}$ Statutes of limitation, in that sense, thus deviate from the general and fundamental position that where there is a wrong there is a remedy. The law expects that a person who has a legal interest to protect would take the necessary legal steps in a timeous manner, as the interest would not enure in perpetuity. The law does not encourage anyone to sleep on his right, possibly snore, and saunter into dreamland and slumber. Then come out when everyone in the community has moved on to begin the agitation for his stale right. That is why the law brings up statutory and equitable defences to aid the vigilant against the indolent. It is also meant to safeguard the society which is covered by the well-crafted public policy that there should be an end to litigation. ${ }^{17}$

It has been held that the principle of statute of limitation of action is premised on the notion that no one should remain under threat of being sued indefinitely and that the right to enforce a claim through the judicial processes of a court of law should not be forever. ${ }^{18}$ The rationale for the existence of such statutes is premised on the following factors:- a) that long dormant claims have more cruelty than justice in them. b) that the person against who they might be made may have lost the requisite evidence to disprove the claim due to passage of time c) that a person with good cause of action should pursue them with reasonable diligence. ${ }^{19}$

Statutes of limitation define when and how a cause of action may be litigated. They do not confer substantive rights per se but render it legally impossible for affected rights to be actualised in court. To that extent they are procedural rights rather than substantive rights. In Akwa Ibom State House of Assembly \& Ors v. Mbom, ${ }^{20}$ the Court made the point that:

\footnotetext{
15 See: Ibrahim v Judicial Service Committee Kaduna State (1998) 14 NWLR (Pt. 584) 1; Obiefuna v Okoye (1961) 1 All NLR 357; Egbe v Adefarasin (NO.2) (1985) 1 NWLR (Pt.3) 549; Fadare v A.G., Oyo State (1982) 4 SC 1; Abubakar $v$ Governor of Gombe State (2002) 17 NWLR (Pt.797) 533.

${ }^{16}$ See: Attorney-General of Rivers State v. Gregory Obi Ude (2006) 17 NWLR (pt. 1008) 436); Akapo v. Hakeem-Habeeb (1992) 7 SCNJ 143

${ }^{17}$ See Akpadiaha v. Uko (2017) LPELR-42635(CA)

${ }^{18}$ See Civil Service Commission \& Anor V. Akwa Ibom State Newspaper Ltd \& Anor (2013) LPELR-21138(CA)

${ }^{19}$ See: Egbe v Adefarasin (1987) 1 NWLR (47) 1 at 20; Aremo II v. Adekanye (2004) 7 SC (Pt. II) 28; Horikolo v. AGF (2003) FWLR (184) 349 at 363.

${ }^{20}$ (2018) LPELR-44788(CA)
} 


\begin{abstract}
"Invariably, the statutory limitation [Limitation Law] is most indisputably procedural, thereby setting time frame within which a suit must be instituted in a Court or Tribunal. ${ }^{\prime 21}$
\end{abstract}

As well as being procedural, it is worth noting that a statute of limitation is a matter of jurisdiction, hence it can be raised at any stage of proceedings. In Nasir v. Civil Service Commission Kano State $\&$ Ors. ${ }^{22}$ the Supreme Court made this point as follows:

"the statute of limitation is a matter of jurisdiction which can be raised at any stage of litigation, and I will add here, even in the Supreme Court. In my words, in the very recent case of FRN v. GOLD 200711 NWLR part 1044 page 1 which has been cited by the learned counsel for the respondents:- "There is no doubt this rule connotes mandatory procedure, but it does not preclude a party from raising the defence of statute of limitation at an appellant court, vide leave to do so even if he did not do so at the Court of first instance, because such issue borders on the fundamental issue of jurisdiction. The appellant in this case realized its mistake in not thrashing out the issue and so raised it in the Court of Appeal after leave was obtained." Per Mukhtar, J.S.C. (P. 17, paras. C-G)

Given its nature as a rule of mandatory procedure, the period specified in a statute of limitation, unlike timelines specified in the rules of court, cannot be waived or extended. ${ }^{23}$ In El-Rufai v. Senate of The National Assembly \& $\mathrm{Ors}^{24}$, the Court of Appeal held that:

"The Public Officers Protection Act by its Section 2(a) is a statute of limitation. The law seems quite settled that a time specified in a statute of limitation for filing an action cannot be extended by the court, unless the statute itself has made provision for extension of time...." Per Adumein, J.C.A. (P. 44, paras. A-C) ${ }^{25}$

A statute of limitation may not, however, defeat a cause of action in cases of fraud, lack of capacity, acknowledgment, disability, etc. ${ }^{26}$ In such cases, the veil of the statute would be lifted to grant audience to the merits of the matter.

\title{
Statute of Limitation and Nigerian Federalism
}

The Constitution of the Federal Republic of Nigeria 1999 ("the Constitution") divides legislative powers between two main tiers of government: the Federal Government and the government of a

\footnotetext{
${ }^{21}$ See also Chigbu v. Tonimas Nig. Ltd. [2006] NWLR [Pt. 984] 189.

22 (2010) LPELR-1943(SC)

${ }^{23}$ See El-Rufai v. Senate of The National Assembly \& Ors (2014) LPELR-23115(CA).

${ }^{24}$ Supra

${ }^{25}$ See Congress for Progressive Change v. INEC \& 41 Ors (2011) 18 NWLR (Pt. 1279) 493.

${ }^{26}$ See: Administrator \& Executors of Estate of General Sani Abacha v. Eke Spiff \& Ors (2003) 1 NWLR (Pt. 800) 114; Lawal \& Ors v. Executive Governor, Lagos State \& Ors (2017) LPELR-43047(CA).
} 
state. ${ }^{27}$ Generally, legislative powers are divided between these tiers of government in the manner prescribed in the Exclusive Legislative List and the Concurrent Legislative List contained in the Second Schedule of the Constitution. Items on the Exclusive Legislative List can only be legislated on by the National Assembly. Items on the Concurrent List can be legislated on by both the federal and state legislatures, with the caveat that federal legislation shall override state legislation where there is a conflict between them. ${ }^{28}$

There are cases where a subject matter is neither contained in the Exclusive Legislative List nor in the Concurrent Legislative List. In such cases, the courts would look first at whether the subject matter can be deemed incidental or supplementary to any of the items contained in the Exclusive Legislative List. If yes, then the National Assembly would have exclusive legislative power to legislate on that subject matter as if it were contained in the Exclusive Legislative List. ${ }^{29}$ If the answer is no, then the subject matter would be deemed residual. It falls within the residue of the legislative powers of the states. ${ }^{30}$ On residual matters the National Assembly can only legislate for the Federal Capital Territory, Abuja ("FCT"), whilst each state is entitled to legislate for itself, without Federal interference. ${ }^{31}$

Item 35 of the Exclusive Legislative List empowers the National Assembly (exclusively) to legislate on "legal proceedings between Governments of States or between the Government of the Federation and Government of any State or any other authority or person."

The law is settled that where the wordings of a statute are clear and unambiguous, they should be given their ordinary meaning. ${ }^{32}$ In our view, the above provision of the Constitution is clear to the effect that only the National Assembly can legislate on legal proceedings between, inter alia, the Government of the Federation and any other authority or person. To that extent, it is elementary that any state law that purports to govern such legal proceedings would be null and void. ${ }^{33}$

\footnotetext{
${ }^{27}$ See generally section 4 of the Constitution. The legislative powers of the Federal Government are vested in the National Assembly, whilst the legislative powers of a state are vested in the House of Assembly of that state.

${ }^{28}$ See section 4(5) of the Constitution. See: Military Governor of Ondo State \& Anor v. Victor Adegoke Adewumo (1988) 6 SCNJ 151; Olaleye-Ote vs. Babalola (2012) 14 NWLR (Pt.1279) 574.

${ }^{29}$ See Item 68 of the Exclusive Legislative List. See also A.G. of Ogun State v. Aberuagba (1985) NWLR (Pt.3) 395; A.G. of the Federation v The A.G. of Lagos State16 NWLR (Pt 1380) 249; Nigerian Soft Drinks v AG Lagos State (1987) 2 NWLR (pt. 57) 444.

${ }^{30}$ See: UAC of Nigeria Plc \& Ors. v. A-G of Lagos State \& Ors. (2010) LPELR-5038(CA); A.- G., Lagos State v. A.-G., Federation (2003) 12 NWLR (Pt. 833); Balonwu v. Obi (2007) 5 NWLR (Pt. 1028) 488.

${ }^{31}$ See: section 4(7) of the Constitution; AG Abia State \& 2 ors v. AG Federation \& ors (2006) 16 NWLR (pt. 1005) 265; A-G Abia State \& 2 ors v. A-G Federation \& ors (2002) 6 NWLR (pt. 764) 542.

${ }^{32}$ Abacha v. FRN (2014) LPELR-22014(SC) Bernard Amasike vs. Registrar General Corporate Affairs Commission \& Anor. (2010) 5 - 7 SC (Pt.1) 147; Bronik Motors Ltd \& Anor. vs Wema Bank Ltd. (1983) NSCC 226

${ }^{33}$ See Attorney-General of the Federation v Attorney-General of Lagos State (supra).
} 
It is also evident that the above constitutional provision is concerned with the parties. It does not relate to the subject matter. Thus, it would seem, on the face of it, that regardless of the subjectmatter of dispute, if an action is between the Government of the Federation and any of the parties contemplated in Item 35, only an Act of the National Assembly can govern such proceedings. It is, perhaps, worth reiterating the point that limitation laws by their character are procedural laws. Bearing that position in mind, it would appear that since only the National Assembly can legislate on legal proceedings involving the Federal Government and any person, only statutory provisions enacted by the National Assembly can limit the time within which proceedings may be commenced by or against the Federal Government (including an agency or authority of the Federal Government).

It is, perhaps, worth noting that the power of the National Assembly under Item 35 to legislate on legal proceedings (particularly limitation of actions) has been exercised through various statutes. For instance, the Public Officers Protection Act limits the time in which an action may be brought against a public officer for any act done in pursuance or execution or intended execution of any Act or Law or of any public duty or authority, or in respect of any alleged neglect or default in the execution of any such Act, Law, duty or authority. ${ }^{34}$ This legislation has been applied by the courts in an avalanche of cases. ${ }^{35}$ There are also some subject-specific Federal statutes which limit the time within which legal proceedings may be instituted under those statutes or against the public authorities established by those statutes. ${ }^{36}$

It is worth reiterating that Item 35 is predicated on whom the parties are. ${ }^{37}$ The Constitution does not expressly confer on the National Assembly the power to legislate on legal proceedings involving specific subject matters (even those on the Exclusive Legislative List). The next thing to look at is whether, in terms of subject matter, limitation of action can be tied to any federal legislative powers, in which case an incidental power may be inferred. The Exclusive Legislative List consists of various Items which only the National Assembly may legislate on. These includes matters such as: taxation, aviation, customs and excise, banking, passports and visas, nuclear energy, mines and minerals, meteorology, etc. ${ }^{38}$ Item 68 of the Exclusive Legislative List provides that the National Assembly shall have power to legislate on any matter incidental to the subjects contained in Items $1-66$. What is the scope of these incidental powers? In every case it is a question of construction. It is like hot oil in a frying pan which must be brought down with caution. The Supreme Court has stressed the importance of caution in delineating the boundaries of "incidental" legislative powers so that the ambit of what is incidental would not be overstretched to encroach on the residual legislative powers

\footnotetext{
${ }^{34}$ See Section 2 of the Public Officers Protection Act, Cap P41 LFN 2004.

${ }^{35}$ See for instance: Aiyetan v. The Nigerian Institute of Oil Palm Research [1987] NWLR (Part 59) 48 (SC), AG Rivers State v. AG Bayelsa State \& Anor. (2012) LPELR-9336(SC), Ibrahim v. Lawal \& Ors (2015) LPELR-24736(SC), INEC v. Ogbadibo Local Government \& Ors (2015) LPELR-24839(SC).

${ }^{36}$ See for instance: section 53 of the Nigerian Maritime Administration and Safety Agency Act, 2007: section 24 of the Civil Aviation Act 2006.

37 This appears to be irrespective of the subject matter or the place of commencement of the proceedings.

${ }^{38}$ See generally Part 1 of the Second Schedule to the Constitution.
} 
of a state. ${ }^{39}$ The question, therefore, is whether the National Assembly's power to legislate on the subject matters in the Exclusive Legislative List also confers an incidental power to legislate on legal proceedings relating to those subject matters. If the answer is in the affirmative, then only an Act of the National Assembly may limit actions brought pursuant to such subject matters, regardless of whom the parties to the action may be and regardless of where the action is commenced. A consequence of this finding is that the limitation law of a state would not apply to such proceedings even if the cause of action arose from that state or even if the action were commenced in that state. This would, no doubt, confine a state's power to limit actions commenced in its territory to actions that are founded on concurrent or residual matters. Would this position amount to an overstretch of Federal legislative power and, thus, an incursion into state legislative territory?

In Benson v Mobil Producing Unlimited, ${ }^{40}$ the Court of Appeal declined to apply the limitation law of the state where the lawsuit was brought with respect to a subject matter on the Exclusive Legislative List. The claim was for compensation for damage caused by an oil spill. The Oil Pipelines Act - a Federal legislation which relates to an item on the Exclusive Legislative List provides a procedure for claiming compensation in such circumstances. The Court suggested that since no limitation period was prescribed in the Oil Pipelines Act, the Limitation Law of Bayelsa State, where the cause of action arose, was inconsistent with the Oil Pipelines Act and was, thus, inapplicable. According to the Court:

"My attention has been drawn to the case of JOHN EBOIGBE (for himself and on behalf of six other member) V. NNPC (1994) 5 NWLR (PT 347) Page 649. On page 659 of the report Adio JSC (of blessed memory) had this to say: "Bearing the provisions of section 11(1) of the NNPC Act 1977 and section 4(1) (a) of the Limitation Law Cap 89 of the Laws of Bendel State of Nigeria 1976 which prescribed six years limitation period in mind, the action instituted by the appellant was prima facie statute barred". The respondent relying on this statement canvassed that the state limitation law can apply in respect of a Federal enactment. This cannot with due respect be true in the face of the provision of the 1999 Constitution and in view of the fact that Eboigbe's case was an action in respect of destruction of economic crops. It was not in respect of an item on the exclusive legislative list of the 1999 Constitution. Eboigbe's case (supra) is therefore clearly distinguishable from this case and the statement of Adio JSC in the case turned on the peculiar facts of the case. What is more, the concluding part of the lead judgment of Adio JSC in Eboigbe's case obviates any confusion that might arise on this issue. His Lordship on page 661 of the report said: "The appellant urge this

\footnotetext{
${ }^{39}$ See Attorney-General of the Federation v Attorney-General of Lagos State (2013) LPELR-20974(SC)

40 (2012) LPELR 14241
} 
court to take into consideration the provision of section 25(c) of the Limitation Law which provide that time should not begin to run until the plaintiff has discovered the fraud, where fraud is alleged, or his mistake; section 28 of the Law which empowers a court to refuse the relief on the ground of acquiescence; and section 21 of the Law which provides that time should not begin or continue to run when a party is under disability. Whatever may be the merit, if any, of the submission, the provisions of the Limitation Law suspending the running of the limitation period prescribed in the Law do not apply as the provisions of section 11(1) of the Nigeria National Petroleum Corporation Act, 1979, are applicable notwithstanding anything in any other enactment." Per Awotoye J.C.A. (Pp. 17-18, paras. A-D)

The Benson decision supports the view that limitation of actions relating to petroleum is incidental to the Federal legislative power under Item 39 of the Exclusive Legislative List. ${ }^{41}$ Thus, only the National Assembly may legislate to limit an action of that character.

In sharp contrast with the Benson case, the Court of Appeal has in cases such as SPDCN v. Dodoye West ${ }^{42}$ and SPDCN Ltd $v$. Chief Zedie Williams \& 2 Ors. ${ }^{43}$ ruled that a state limitation law was applicable to any action commenced in the territory of that state irrespective of whether the cause of action relates to a subject-matter on the Exclusive Legislative List.

In SPDCN v. Dodoye West, ${ }^{\mathbf{4}}$ the Court held that the Limitation Law of Rivers State was applicable to actions resulting from the Oil Pipeline Act within Rivers State since a claimant could not be allowed to wait for an indefinite period of time after the accrual of his right to seek judicial redress. The Court held that whilst there was no limitation period in the Oil Pipeline Act, there was also nothing in that statute which precluded a defendant from raising a plea of limitation under another statute, even if a state statute. The Court, in reaching this decision considered and rejected its own decision in Benson:

"I have noted that in his Ruling delivered on 25th March, 2015 the learned trial Judge relied on this Court's decision in BENSON V. MOBIL PRODUCING (NIG) UNLTD (2014) ALL FWLR \{Pt. 722\} 1821 - 1822 to dismiss the appellant's Preliminary Objection. However, the two previous decisions of this Court (quoted above) pronounced that a State's Statute of Limitation is binding on all Courts within the territorial area of that State and the Supreme Court's holding on the rationale or

\footnotetext{
41 "mines and minerals, including oil fields, oil mining, geological surveys and natural gas."

42 Supra

43 (Unreported) Appeal No. CA/PH/667/2014

${ }^{44}$ Supra (the more recent case on the point)
} 
justification supporting the existence of Statute of Limitation in AREMO II V. ADEKANYE (Supra) cannot be ignored. This Court towed the proper line by following the two earlier decisions in its recent judgment in SHELL PETROLEUM DEVELOPMENT COMPANY (NIG) LTD V. CHIEF ZEDIE WILLIAMS \& 2 ORS. Appeal No. CA/PH/667/2014 delivered on 6th December, 2017 where GUMEL JCA pronounced thus: - 'However, because of what I said earlier on the suitability and applicability of the 2 earlier decisions of this Court in SUNDAY ETIM V. I.G.P. (Supra) and COMFORT ASABORO V. PAN OCEAN OIL (Supra) I wish to emphasise that and proceed accordingly without much ado. But just before that may I, with all due respect remark that limitation of time provisions either in specific legislation or general limitation of time stipulations are a public policy imperative that may be said to have emanated from the equitable doctrines developed in England in the $19^{\text {th }}$ Century to ameliorate the characteristic harshness of some common law principles. It started with the equitable maxim that 'equity aids the vigilant and not the indolent. The word 'equity' here being used as a generic term to mean 'justice' or fairness. It may also be added that the current 2004 volumes of the Laws of the Federation of Nigeria do not contain a Limitation Act, so if the decision in BENSON V. MOBIL (Supra) is to hold sway, there would then be no time limitation for any cause of action that arose out of the provisions of a Federal enactment or matters within the Exclusive Legislative List. The effect of the decision in BENSON V. MOBIL (Supra) will then appear to have done the impossible, i.e. overruling 2 previous decisions of the same Court.'

I am obliged to follow this decision by GUMEL JCA because I was a member of the panel that concurred with same in my contribution to the well-considered judgment of my learned brother in the lead judgment. It is therefore my holding that the learned trial Judge was in error when he held that Section 16 of the Rivers State Limitation Law, Cap 80 of 1999 does not apply to this suit. Suit No. FHC/PH/CS/294/2013 filed on $28^{\text {th }}$ August, 2013 is statute barred because the cause of action accrued on $20^{\text {th }}$ July, 2006 which is more than the five (5) years prescribed in Section 16 of the Limitation Law of Rivers State." ${ }^{45}$

\footnotetext{
${ }^{45}$ From this quote, it is evident that a significant basis of the criticism leveled against the Benson decision by the Court - and a point of departure - is the idea that there would be an absurd vacuum (where there would be no limitation at all) if the state limitation law was precluded, since the Federal statute did not prescribe any limitation period. The question is, what if there was, likewise, no state limitation period applicable to the subject matter in the state where the action was filed? Would the defendant then be allowed to import a limitation provision from anywhere it could be found? Our view is that the absence of limitation period in a statute does not mean that an action may be brought at any time the plaintiff pleases. It is worth remembering that statutes of limitation derive their origin from equity. The follow-up question is, absent a statutory limitation period, can a defendant, in appropriate circumstances, not successfully fall back on equity to plead that the plaintiff has overslept on his perceived rights and should therefore be precluded from maintaining the action?
} 
In an earlier case, Asaboro v. Pan Ocean Oil (Nig.) Ltd., ${ }^{46}$ the appellant contended, inter alia, that neither the Petroleum Act nor any regulation made thereunder prescribed any period within which a claimant may commence an action against the holder of an oil mining lease claiming fair and reasonable compensation, and that in the absence of such provision it would be erroneous to presume or import a statute of limitation into the case. The Court rejected this submission. According to the Court:

"With due respect to the learned counsel if it is intended to exclude claims arising from the Petroleum Act and the Regulation thereunder there would have been express provision to that effect either in the Act or in the Regulation made pursuant to same. It cannot be correct or the intention of the law that a claimant, as learned counsel would imply, could wait for an indefinite period of time after the accrual of his right to seek redress.” Per Ngwuta JCA (as he then was) at p. 617 paras $\mathrm{H}-\mathrm{B}$.

The above decisions, in some respects, find higher judicial support in a Supreme Court authority, Eboigbe \& Ors $v$ NNPC,${ }^{47}$ wherein the apex Court applied the Limitation Law of Bendel State to a claim against the respondent, an agency of the Federal Government, in a claim for damage to the appellant's crops allegedly caused by the respondent. Eboigbe was brought to the attention of the court in the Benson case, but the court elected to distinguish Eboigbe on the ground that the subject matter of the claim in Eboigbe, damage to the plaintiff's crops, was not on the Exclusive Legislative List.

\section{Was the Court of Appeal in Benson entitled to not follow the Supreme Court decision in Eboigbe?}

The firmly-established rule of stare decisis is to the effect that the decision of a higher court on a particular issue constitutes binding authority on a lower court faced with a similar issue. ${ }^{48}$ This makes for certainty of the law. ${ }^{49}$ It is also a firmly-rooted feature of stare decisis that a case is only an authority in respect of what it decides. ${ }^{50}$ Thus, every case must be related to its specific facts and the issues considered. Failing this blueprint would amount to citing the case out of proper context. In Eboigbe, the issue of whether the limitation law of a state may apply to an action founded on a Federal subject matter was not considered. To that extent, we can state that Eboigbe is not an

\footnotetext{
46 (2006) 4 NWLR (pt. 971) 595

${ }^{47}$ (1994) 5 NWLR (Pt 347) 649

${ }^{48}$ See Obiuweubi v. C.B.N. (2011) 7 NWLR (Pt. 1247) 465 S.C; Nigeria Agip Oil Company Ltd v. Nkweke \& anor (2016) LPELR-26060(SC); PDP v. Oranezi \& Ors (2017) LPELR-43471(SC)

${ }^{49}$ See Eperokun vs. University of Lagos (1986) 4 NWLR (pt. 34) 162; Inc'd Trustees of Holy Apostles Church, Ayetoro \& ors v. Inc'd Trustees of Oneness Faith of Christ Ministry, Ayetoro \& ors (2016) LPELR-41368(CA); Ojukwu v. Agupusi \& anor (2014) LPELR-22683(CA)

${ }^{50}$ See: Okafor \& 3 ors. v. Nnaife. (1987) 4 NWLR (Pt.64) 129; Tanko v. The State (2009) LPELR-3136(SC); PDP v. INEC \& Ors (2018) LPELR-44373(SC).
} 
authority to the effect that a state legislation can limit actions founded on a subject matter in the Exclusive Legislative List. It is worth noting also that the subject matter of the Eboigbe case was tortious liability, which is a residual matter. To that extent, the Court of Appeal in Benson was, perhaps, entitled to distinguish the case before it from the Supreme Court's decision in Eboigbe.

\section{Conflicting Decisions of the Court of Appeal}

The law is that where there are conflicting decisions of the Court of Appeal, the Court of Appeal is itself entitled to decide which to follow. ${ }^{51}$ The consistent position taken by the courts on this issue of judicial precedent is that a lower court faced with conflicting decisions of a higher court must follow the latest of those decisions. ${ }^{52}$ Of course, there is also jurisprudence that suggests that where a lower Court is faced with conflicting positions of a higher Court on an issue with one position having one or two decisions of the higher Court in its support and the other position being supported by an avalanche of decisions of the higher Court, it is wiser for the lower Court to follow the position with the larger decisions as against the other position. ${ }^{53}$

With regard to the issue at hand, it goes without saying that the Court of Appeal decision in Benson $v$ Mobil Producing Unlimited conflicts with the other Court of Appeal decisions discussed herein. It seems that the weight of authorities - albeit not an avalanche - leans in favour of the position that a state limitation law does apply to causes of action founded on Federal law in so far as the action is commenced within the territory of that state. Also, the latest of those authorities, SPDC v. Dodoye West, also takes the pro-state limitation law view. This view would, thus, seem to represent the current position of the law. However, given the substantial points raised in the Benson case, as well as in this article, it is our view that until the Supreme Court resolves these issues, the controversy remains, and a prudent litigant must work with both judicial trajectories in mind. After all, another panel of the Court of Appeal may yet, absent a definitive decision of the Supreme Court upholding the opposite line of authorities, chose to go with the Benson position.

\section{A Federal statute of limitation?}

The Limitation Act $2007^{54}$ ("the Limitation Act") prescribes time limits in respect of various actions including actions brought by or against a state authority. Section 68 of the Limitation Act defines the term "state authority" to include "any authority by which the executive power of the Federal

\footnotetext{
${ }^{51}$ See Usman v Umaru (1992) 7 NWLR (PT 254) 377.

${ }^{52}$ See: Ikeni v. Efamo (2001) 10 NWLR part 720 p.1; Alao v. V.V.C Unilorin (2008) 1 NWLR (Pt. 1069) 421; Daru \& Ors v. Umar (2013) LPELR-21905(CA); Chief Okpozo v. Bendel Newspaper Corporation \& Anor. (1990) 5 NWLR (Pt. 153) 652; Mkpedem v. Udo (2000) 9 NWLR (PT. 673) 63; Nwangwu v. Ukachukwu (2000) 6 NWLR (PT. 662). This position is a departure from some authorities which hold that the lower court is at liberty to choose. See Adegoke Motors Limited v. Adesanya \& ORS (1987) LPELR-20498(CA).

${ }^{53}$ See Onuoha v. State (1989) 1 NSCC 411; Obiakor \& Ors v. Okafor (2017) LPELR-43309(CA)

${ }^{54}$ Cap 522 Laws of the FCT 2007
} 
Government is duly exercised in a particular case." The state authorities expressly excluded from the application of the Limitation Act are the Federal Inland Revenue Service and the Board of Customs and Excise. ${ }^{55}$ It is often said in law that the express mention of a thing is the exclusion of another not mentioned. ${ }^{56}$ Thus, the implication of these provisions is that the Limitation Act would apply to actions brought by or against any "state authority" that is not expressly exempted.

\section{Validity and scope of the Limitation Act}

As we have asserted, the National Assembly, arguably, has powers to make law to: 1. limit actions by or against the Federal Government (exclusive legislative powers); 2. limit actions brought pursuant to a subject matter on the Exclusive Legislative List (incidental legislative powers); 3. limit actions brought within the FCT (residual legislative powers). The Limitation Act, as currently drafted, touches on each of these legislative powers. However, the scope of the application of the Limitation Act is questionable on some grounds.

The first ground to challenge the application of the Limitation Act is that it is omitted from the consolidated Laws of the Federation. The Laws of the Federation have been consolidated three times since the Limitation Act was enacted in 1966. These were in 1990, 2004 and 2010. On each occasion the Limitation Act was omitted. Rather, the Limitation Act is included in the Laws of the FCT. This situation conveys the impression that the application of the Limitation Act is restricted to the FCT.

\footnotetext{
${ }^{55}$ It is also specified that the Limitation Act will not apply where another enactment has fixed the limitation period (such as the NIMASA Act and the Public Officers Protection Act) or to an action in respect of which a limitation period would ordinarily be fixed by another enactment if the parties involved were private individuals. In the latter case the state authority would be treated in the same manner as a private individual. See section 4 of the Limitation Act. The question is in what actions would a state authority ordinarily be treated in the same manner as a private person. Our view on this is that a state authority would ordinarily be treated as a private individual where the subject matter of the dispute is not within the Exclusive Legislative List or where the action is not in respect of something done in exercise of administrative authority. In reaching this conclusion, we lean on the well-established principle relating to the application of section 251(1)(p)(q) \& (r) of the 1999 Constitution. Those provisions confer special status on "state authorities" to the extent that actions relating to the exercise of their executive or administrative powers may only be commenced before the Federal High Court. See NEPA v. Edegbero (2002) 18 NWLR (pt. 798) 79. However, where a claim by or against a "state authority" borders on non-administrative subject matters such as tort and simple contract, the action may be brought before courts other than the Federal High Court. In respect of such non-administrative actions a "state authority" is treated in the same manner as a private individual. See Onuorah v. K.R.P.C. (2005) 6 NWLR (pt.921) pg.393. Juxtaposing the foregoing position, we submit that the implication of section 4 of the Limitation Act is that in cases of such ordinary character the Limitation Act would not apply, except in the FCT. For illustrations, if a simple contract claim is instituted against a "state authority" in a state such as Lagos, the Limitation Act would not apply but the Limitation Law of Lagos State would apply. Conversely, if a case bordering on the administrative powers of a "state authority" is instituted against that "state authority", the Limitation Act would apply regardless of the territory. In the latter case, the "state authority" is being sued for an official act and not for a "private transaction" where it would be treated in the same manner as a private individual. To buttress these points, we refer to the case of Osun State Government v. Dalami Nigeria Ltd (2007) LPELR-2817(SC) where it was held that the Public Officers Protection Act does not apply to contract disputes. This is because the Act seeks to protect public officers/institutions in the exercise of administrative functions and not when disputes arise from their private-like engagements.

${ }^{56}$ Sun Insurance Nigeria Plc v. Umez Engineering Construction Company Ltd (2015) LPELR-24737(SC)
} 
This is despite significant provisions which make the Limitation Act applicable to actions brought by or against state authorities (without qualifications as to where an action is commenced).

Does the omission of the Limitation Act from the Laws of the Federation support the conclusion that the Limitation Act has no application outside the FCT? It is settled law that the courts do not presume a statute repealed by implication. Where it is intended to repeal a legislation, it must be expressly so stated by another legislation made by the relevant legislative authority. This is founded on the principle that only parliament can repeal an Act of parliament. ${ }^{57}$ In like manner, a statute should not be deemed redundant or nugatory simply because it is omitted from the consolidated laws. In Ibidapo v. Lufthansa Airlines ${ }^{58}$ the Supreme Court held that the fact that a statute has been omitted from the consolidated laws does not, of itself, mean that the statute ceases to exist. In the light of the above, it is our view that the Limitation Act does not cease national application by virtue of its omissions from the Laws of the Federation and may subsist "federally" to the extent of the legislative powers of the National Assembly.

In Etim v. Inspector-General of Police, ${ }^{\mathbf{5 9}}$ the Court of Appeal declined to apply the Limitation Act (then the Limitation Decree), holding that the application of the Limitation Act was limited territorially to actions commenced in the FCT. The Court relied on the then section 71 of the Limitation Act which stipulated that the Limitation Act "shall apply to the Federal Territory only." The Court also relied on the provision of section 13 of the Federal Capital Territory Act ("FCT Act") which incorporates the Limitation Act as one of the legislations applicable in the FCT. ${ }^{60}$ The Court further relied on its previous decision in Raleigh Industries (Nig.) Ltdv. Nwaiwu ${ }^{\mathbf{6 1}}$ where it held that the Limitation Act was only applicable to actions commenced in the FCT. The Court held on these bases that the Limitation Act was only applicable to actions commenced in the FCT. The Court further held that the Limitation Edict of Kaduna State was applicable to any action commenced in Kaduna State irrespective of the court, parties or where the cause of action arose. According to the Court:

"The position however is not the same with regard to the reliance by the lower court on the Limitation Edict CAP 89 Laws of Kaduna State. It therefore applied to any action filed in any court of law in Kaduna State including of course the Federal High Court sitting in Kaduna where the appellants' chose to file their action against the respondents. The law applies to any court operating within the territorial area of Kaduna State without regard as to who the parties in the action are. The word 'action' is in fact defined in section 3 of the law to include any proceeding (other

\footnotetext{
${ }^{57}$ See Akintokun v. LPDC (2014) LPELR-22941(SC).

58 (1997) 4 NWLR (Pt.498) 124

59 (2001) 11 NWLR (pt. 724) 266

${ }^{60}$ See the Second Schedule to the FCT Act

61 (1994) 4 NWLR (pt. 341) 760
} 
than a criminal proceeding) in a court established by law of which the Federal High Court Kaduna is definitely one. In this respect, the lower court was quite right in applying the law to the present case before it in deciding on the appellant's claims."

In this case, the cause of action was breach of contract of employment. The defendant/respondent was a "state authority" within the meaning of the Limitation Act and a resident of the FCT. At the risk of repetition, it is implicit from the Court's pronouncement that a state limitation law would apply to any civil subject-matter brought within the territory of that state irrespective of the parties or the subject-matter. Conversely, the Limitation Act would only have applied if the action was instituted in the FCT.

Section 4(1) of the Constitution vests the legislative powers of the Federation in the National Assembly. The National Assembly is conferred with powers to make law for the peace, order and good governance of Nigeria in accordance with its constitutional mandate. The National Assembly is also empowered to make laws for the FCT in the same manner as a State House of Assembly would make laws for a state. Furthermore, section 315 of the Constitution provides that, subject to the provision of the Constitution, an existing law shall have effect with such modifications as may be necessary to bring it into conformity with the provisions of the Constitution, and shall be deemed to be an Act of the National Assembly to the extent that it is a law in respect to any matter on which the National Assembly is empowered by the Constitution to make laws. The Constitution also empowers the President, as "the appropriate authority" to modify an existing law as he deems necessary or expedient to bring it into conformity with the provisions of the Constitution. ${ }^{62}$

The implication of the foregoing provisions is that the National Assembly may amend the provisions of any Federal legislation. Also, where a law survives the military-to-civilian transition of Nigeria as a Federal existing law, the President may make necessary conformist modifications to it. At the time Raleigh and Etim were decided, the Limitation Act contained a section 71 - quoted above which limited its application to the FCT. That provision now stands deleted as it is no longer present in the subsisting Limitation Act contained in the Laws of the FCT 2007. ${ }^{63}$ Importantly, the provisions which made the Limitation Act applicable to proceedings by or against a "state authority" remain. ${ }^{64}$ This raises the inference that the restrictions on the scope of application of the Limitation Act identified in the Raleigh and Etim cases have been done away with. In order words, the Limitation Act should now apply to proceedings commenced by or against a state authority even if the venue is outside the FCT. ${ }^{65}$

\footnotetext{
${ }^{62}$ Section 315(2) of the Constitution. See Attorney-General of Abia State \& Ors v. Attorney-General of the Federation (2003) LPELR-610 (SC)

${ }^{63}$ One wonders whether the Court of Appeal would have reached a different position on the application of the Limitation Act if the now deleted section 71 did not exist at the time when Raleigh and Etim were decided.

${ }^{64}$ See section 1 of the Limitation Act

${ }^{65}$ For exceptions, please see section 4 of the Limitation Act.
} 
To add to the above point, it is worth highlighting that the language of section 13 of the subsisting FCT Act merely states that the statutes listed in its Second Schedule "shall apply in the Federal Capital Territory." It does not state that those laws shall apply only in the FCT. The cumulative implication, in our view, is that the scope of some of those statutes would extend beyond the FCT in so far as they deal with issues within the legislative competence of the National Assembly as a Federal legislature. Indeed, there are several statutes which, like the Limitation Act, are listed in the Second Schedule of the FCT Act that, nevertheless, in appropriate cases, apply outside the FCT. ${ }^{66}$ Thus, if legal proceedings are commenced by or against an authority of the Federal Government in a court of law outside the FCT, section 13 of the FCT Act should not prevent a party from relying on the Limitation Act.

\section{Limitation of action on a state-to-state basis}

The conflict of laws challenge in the application of statutes of limitation is not limited to the Federal vs state law angle. There may also be conflicts regarding multiple state laws. As earlier illustrated in this paper, it is possible to have a cause of action that crosses state lines. In such cases one may be confronted with uncertainty as to which state's limitation law applies. Take for instance a contract case where the contractual breach occurs in the state of expected performance, but the prospective defendant resides in a different state. The law allows the claimant to institute the action in the state where the contract was to be performed or where the defendant resides. ${ }^{67}$ The Limitation Laws of these states may contain different limitation periods. Indeed, due to the differences in limitation periods, the action may be statute-barred in one state whilst remaining open to litigation in the other state. Which limitation law should apply in situations of such conflict? The case of Etim v. InspectorGeneral of Police $e^{68}$ is authority to the effect that the court is entitled to apply the limitation law of the state where the action is instituted (which may be where the Defendant resides) and not that of the state where the cause of action arose (e.g. where the alleged breach occurred).

\footnotetext{
${ }^{66}$ Examples are the Capital Gains Tax Act, the Stamp Duties Act, the Court of Appeal Act, the Oaths Act, the National Library Act, the Public Officers Protection Act, the Sheriffs and Civil Process Act and the Arbitration and Conciliation Act. The Oaths Act, notably, applies throughout the Federal Republic of Nigeria and is used for depositions made at the registries of all Federal courts in Nigeria (the Court of Appeal, the Federal High Court, the National Industrial Court, etc.) irrespective of where these courts are located. It is a notorious fact that all Federal courts in Nigeria have judicial venues or judicial divisions outside the FCT. It is notable that "Oaths and affirmations" is neither a matter in the Exclusive Legislative List nor the Concurrent Legislative List.

${ }^{67}$ See Order 4 Rule 1(3) of the High Court of Lagos State Civil Procedure Rules 2019; IK Martains (Nig.) Ltd V. U.P.L (1992) 1 NWLR (Part 217) Page 322; Megatech Engineering Ltd v. Sky Vision Global Networks LLC (2014) LPELR$22539(C A)$.

${ }^{68}$ Supra
} 


\section{Conclusion}

It has always been in the interest of both litigants and public policy that there should be an end to litigation. Thus, the importance of a statute of limitation in litigation cannot be overstated. It makes for certainty and harmony that the sword of potential litigation should not hang over a person's head in perpetuity. Consequently, a would-be litigant has a profound self-obligation to pursue his claim within a reasonable time. While limitation of action is one of the many offsprings of equity, statutes of limitation are commonplace in the legal systems of countries such as Nigeria. There, however, remain significant uncertainties in the scope of application of these limitation laws. The judicial authorities discussed in this paper, coupled with the referenced statutory authorities, are integral to the uncertainty. For instance, the issue of whether a state limitation law can apply to an action founded on a Federal subject is far from settled. The issue of whether a state limitation law can apply to proceedings involving a Federal authority in respect of its administrative actions is not settled. Also, the issue of whether the Limitation Act can apply outside the FCT is yet to be settled. Perhaps only a comprehensive decision of the Supreme Court can lay all these uncertainties to rest. Given the subsisting conflict of laws and judicial uncertainty highlighted herein, perhaps a prudent litigant should, where in doubt, plead more than one statute of limitation, albeit in the alternative. The court would then be left to decide whether and which statute of limitation to apply. 